\title{
Utility of Linear Scalp Incision in Various Cranial Surgeries
}

\author{
NASSER MOSAAD, M.D.; MOHAMMED ADAWI, M.D. and RAMI TEAMA, M.D. \\ The Department of Neurosurgery, Faculty of Medicine, Banha University
}

\begin{abstract}
Background: The linear incision and its modifications are the most commonly used incisionsbecause of being simple and having good outcome. Linear incisions have the advantage of easier upward and downward extension.

Layers of the scalp can be arranged as the mnemonic SCALP: S (Skin), C (Connective tissue), A (Aponeurosis), L (Loose areolar tissue), and $\mathrm{P}$ (Pericranium).

Aim of Study: Is to evaluate thesufficiency of linear scalp incisions, and its resultant scar.

Patients and Methods: This is a prospective study performed on 43 cases with different pathologies all of them were operated using linear scalp incision between January 2017 and December 2019 in Neurosurgery Department at Benha University Hospitals.

Results: Forty three cases were operated using linear scalp incision in the period from January 2017 to December 2019 at Neurosurgery Department at Benha University Hospitals. The age of patients in this study ranged from 5 years to 66 years with a mean age of 29 years. The patients in this study were composed of 24 females and 19 males. The follow-up period ranged from 6 months to three years.

Conclusion: Linear scalp incision has a very great safety and efficacy in different types of craniotomies. We found the disadvantages to be present in few cases and can also occur in other types of scars that may be worse than linear incisions and can be minimized by taking care of langers lines and vascular territories of the scalp and minimizing the use of artery forceps.
\end{abstract}

Key Words: Linear-Scalp-Cosmetic.

\section{Introduction}

THE linear incision and its modifications are the most commonly used incisionsbecause of being simple and having good outcome. Linear incisions have the advantage of easier upward and downward extension [1]. Layers of the scalp can be arranged as the mnemonic SCALP: S (Skin), $\mathrm{C}$ (Connective tissue), A (Aponeurosis), L (Loose areolar tissue), and $\mathrm{P}$ (Pericranium) [2] .

Correspondence to: Dr. Nasser Mosaad, The Department of Neurosurgery, Faculty of Medicine, Banha University
Changes that happen at the dermal layer can give a picture about the future scar. Collagen represents $75 \%$ of dry dermal layer and this is of special value in the scalp because of the presence of the galeaaponeurotica. The presence of occipitofrontalis muscle in the scalp give the skin lines a different behavior in relation to other parts of the body-for example, Kraissl'slines have coronal direction, while Langer's lines have sagittal direction [3,4] Fig. (1).

The scalp also contains hair follicles related to skin lines which give the scalp a different position among other parts of the skin. This relation have been studied by many authors and concluded that there is a direct relation between langers lines and the hair follicles direction [4].

The presence of loose areolar connective tissue give the scalp the advantage of simble easy separation during cranial surgery. Stress relaxation and creep are two physical properties that help healing of scalp incisions. Stress relaxation is known as the reduction in the sum of power needed to keep a fixed volume of skin stretch over time; creep is the increase in skin surface area that happens when a fixed power is performed [5] . Accordingto Camirand and Doucet scalp incisions perpendicular to hair follicles are more cosmetic than those parallel ones because of giving the chance to hair follicles to grow through the scar lines [6].

Reduced perfusion and tissue ischemia can happen if the subdermal arteriolar closing pressure resulting from increased wound tension exceeds the blood perfusion pressure, so during wound closure the skin tension must be reduced as possible to avoid this complication [7].

In this study we will review our experience in linear scalp incision used for various cranial and intracranial surgeries. 


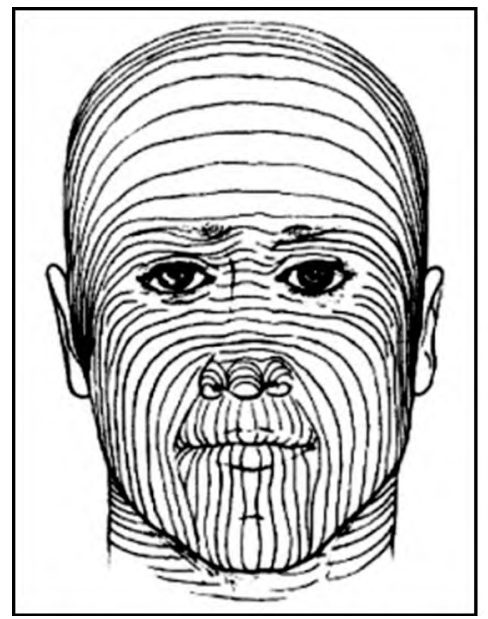

Langer's Lines head from Marx J., Hockberger R., Walls R Ed. Rosen's Emergency Medicine: Concepts and Clinical Practice 2002

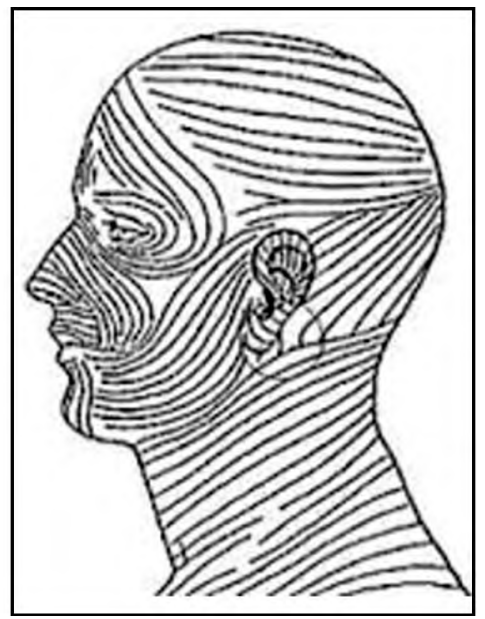

Langer's Lines head from The Open Access Atlas of Otolaryngology, Head \& Neck Operative Surgery by Johan Fagan (Editor) johannes.fagan@uct.ac.za accessed 22 Sept. 2016

Fig. (1): Illustration of langers lines in head and neck (oueted) [4]

\section{Patients and Methods}

This study included 43 cases with different pathologies all of them were operated using linear scalp incision in the Department of Neurosurgery, Benha University in the period between January 2017 and December 2019.

The cases were divided according to pathology into three groups:

- The first group included intracranial tumors, the number of cases in this group were 23 in the form of meningiomas (convexity, parasagittal), gliomas, intraventricular tumors, and CP angle tumors.

- The second group included 13 surgeries for skull lesions and cranioplasty.

- The third group includedtraumatic conditions including 7 cases with epidural hematomas and intracerebral hematomas.

All patientswere operated using linear scalp incision with different length according to size of lesion and aim of surgery. Follow-up was done at 3 months to evaluate the scar and to report any complication.

We tried to follow fixed rules in incision and closure in all wounds as follow:

- The scalpel must be perpendicular to skin to avoid undermining.

- The incision should be parallel to langer's line as much as possible.

- For proper designof theincision, we took in consideration the blood supply of the scalp and the direction of hair growth as growth of hair will cover the scar.
- During closure stitches must be at equal distance and depth on both sides.

- The use of artery forceps was limited to avoid ischemia of the edges.

- Surgical thread used in skin closure was monofilamentous, absorbable, $2 / 0$ on cutting needle.

- Usual post-operative surgical wound care was utilized.

\section{Results}

The age of patients in this study ranged from 5 years to 66 years with a mean age of 29 years. The patients in this study were composed of 24 females and 19 males. The follow-up period ranged from 6 months to three years.

Linear scalp incision was used in all patients of this group. The length of incision ranged from $4 \mathrm{~cm}$ in small scalp swelling about $2 \mathrm{~cm}$ in diameter to $11 \mathrm{~cm}$ in some tumor cases and some traumatic cases. Subgleal drain was used in all cases except for 6 cases ( 4 cases of cranioplasty and 2 cases with $\mathrm{CP}$ angle tumor).

The linear incision provided a sufficient accessibility to perform the desired bone flap without needing modification.

The skin complications were assessed according the Holgers classification system: Grade $0=$ no adverse reaction; Grade 1=skin with erythema; Grade $2=$ skin with erythema and discharge; Grade $3=$ granulation tissue; and Grade 4=inflammation/ infection resulting in the removal of the abutment, minor wound complications include grade $1 \& 2$ while major complications include grade $3 \& 4$ [8] 
Evaluation of the scar was based on width, elevation, and degree of alopecia. Also, patient's responses to the cosmetic results were recorded.

Dring follow-up period 1 patient developed CSF leak that resolved using local wound care. Another case developed local wound swelling that proved to be pseudomeningeocele that required surgical revision of wound. There were 3 cases of wound infection that resolved on regular dressing and antibiotics.

The overall cosmetic results were satisfactory, the most common complication of linear scalp incision that is widening of scar was recorded in 4 cases only and wasn't disturbing to the patient, this increase in scar width was less than $0.5 \mathrm{~cm}$ and was covered with hair, this widening was observed to occur in longer incisions, traumatic wounds, incisions perpendicular to Langer's line and prolonged use of artery forceps causing ischemia to wound edges and in laterally placed incisions (less vascular scalp).
Table (1): Summary the different variables and outcome in our study.

\begin{tabular}{ll}
\hline Variable & Number \\
\hline Mean age (years) & $(29)$ \\
Gender: & \\
$\quad$ Male & $19(44 \%)$ \\
Female & $24(56 \%)$ \\
Pathology: & \\
Tumor & 23 \\
Trauma & 7 \\
Skull pathology\& cranioplasty & 13 \\
Mean Follow-up period & $14(6-36)$ months \\
Complications: & \\
Infection & $3(7 \%)$ \\
Subgleal hematoma & $2(4,7 \%)$ \\
Scar widening & $4(9.3 \%)$ \\
CSF leak & $1(2.3 \%)$ \\
Pseudomeningeocele & $1(2.3 \%)$ \\
Cosmetic outcome: & \\
Excellent & $31(72 \%)$ \\
Good & $8(18.6 \%)$ \\
Widened scar & $4(9.3 \%)$ \\
\hline
\end{tabular}

\section{Illustrative cases:}

Case (1): Twelve years old boy presented with large posttraumatic (5cm diameter) scalp defect in the left posterior parietal region. We performed linear anteroposteior scalp incision centered on the defect with dissection of scalp from the dura till reaching the healthy bone with placement of titanium mesh Fig. (1A).
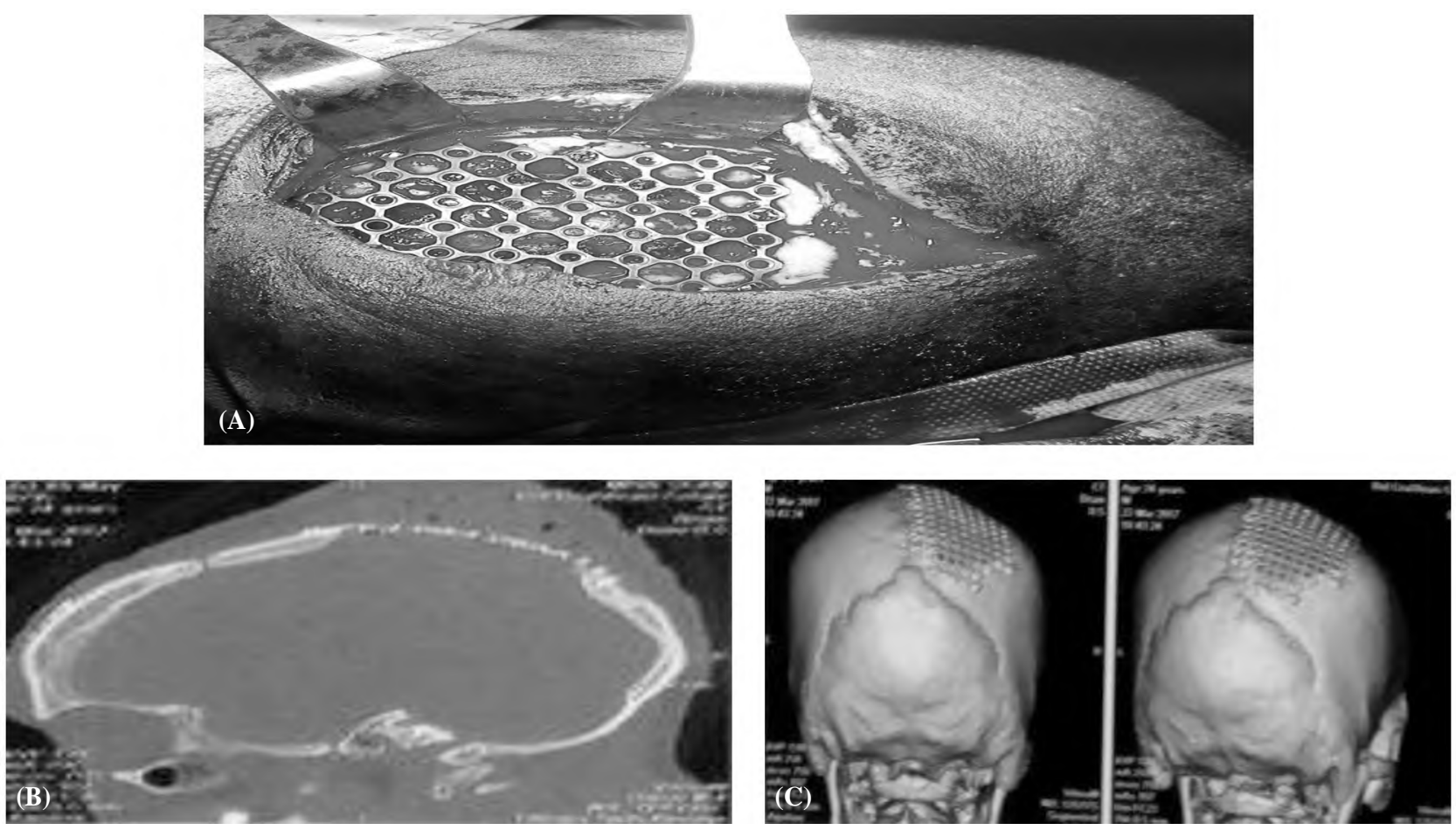

Fig. (1): (A) Intraoperative view showing linear incision in right posterior parital region, (B,C) Post-operative CT brain with reconstruction showing the titanium mesh in place. 
Case (2): Fifty eight years old female with right parasagittal meningioma operated using small linear scalp incision with total tumor removal Fig. (2).

Fig. (2): (A), Pre-operative axial MRI T II showing right sided parasagittal meningioma. (B), Picture taken after removal of stitches with good wound outcome. (C), Post-operative CT brain showing complete tumor removal.
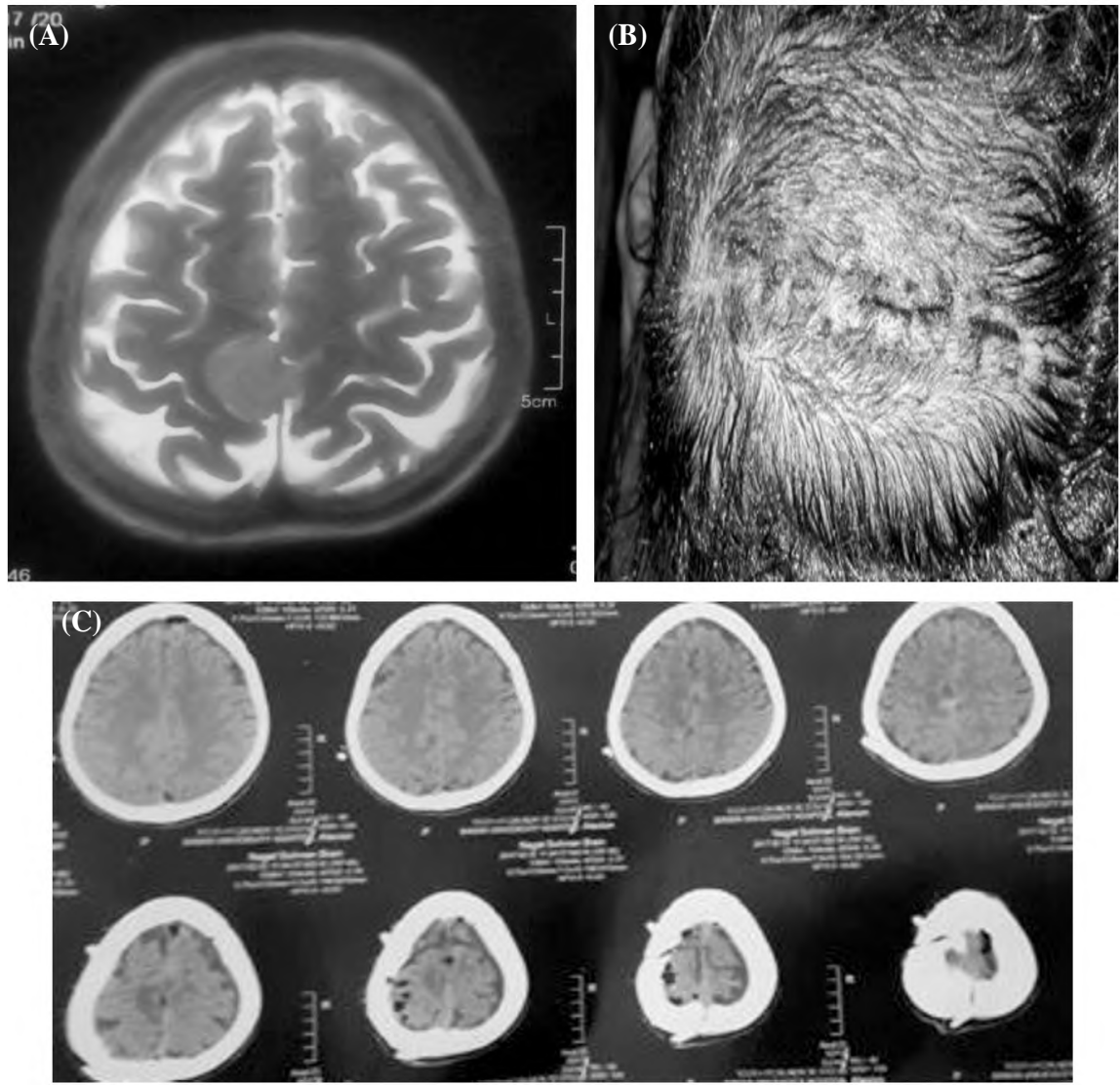

Case (3): Twenty seven years old female with giant left lateral ventricular glioma operated using snteriortranscallosal approach and linear scalp incision with complete tumor removal.

Fig. (3): (A), Pre-operative TI MRI brain without contrast showing giant heterogenous left lateral ventricular mass. (B), Intraoperative view showing the linear incision. (C), Postoperative CT brain showing total tumpor removal.
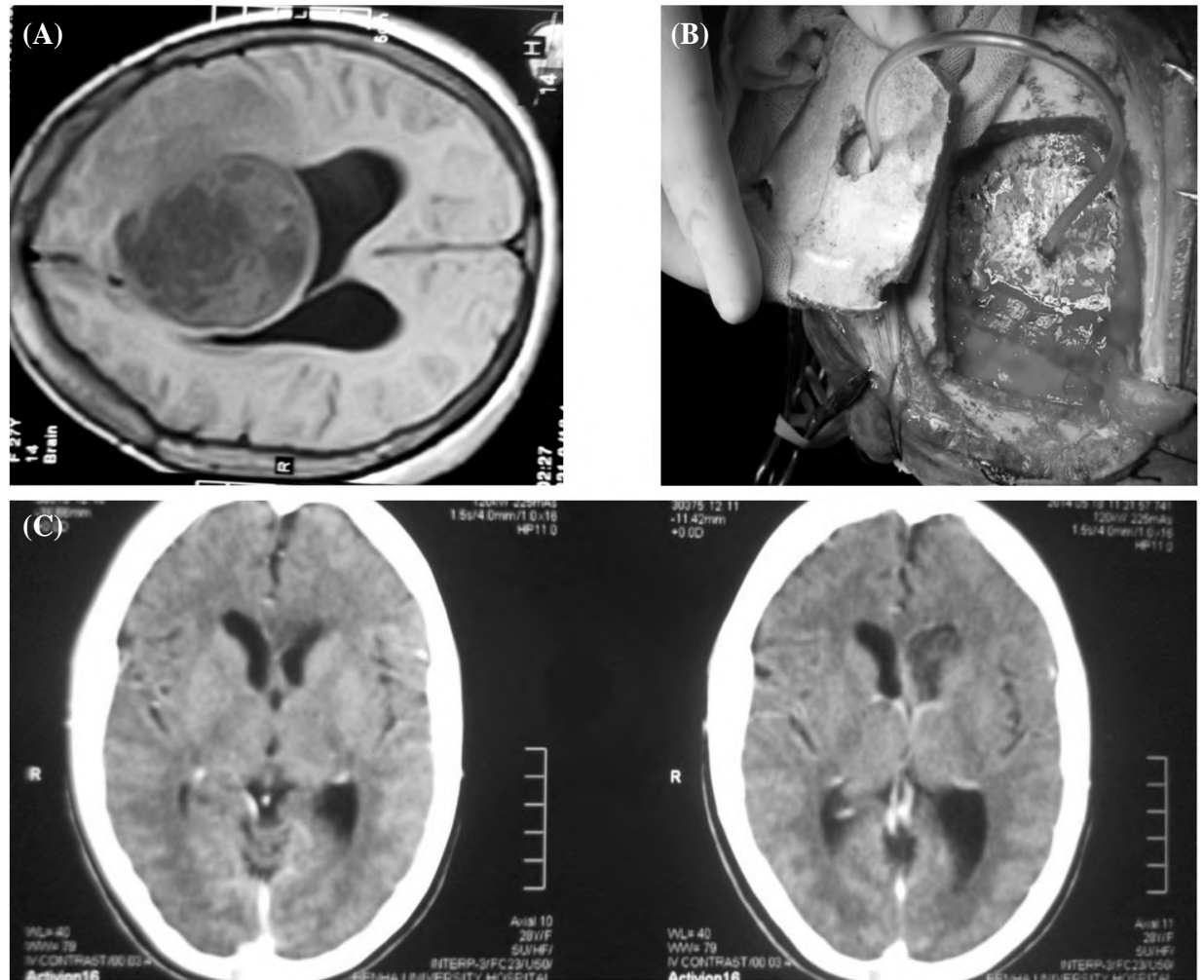


\section{Discussion}

Linear scalp incision is a simple, time saving procedurethat can be utilized safely as the initial step for different surgeries.

In a study performed by William et al., on linear and curvilinear scalp incision in retromastoied approach for cases of microvasculardecompression and vestibular schwannoma, the authors opinion was that the linear incision is a good choice regarding simplicity and efficiency, it also take less time and give protection to underlying muscles, vessels and nerves which is compatible with results of our study in safety and efficacy of linear scalp incision [1].

Another study performed by Frodel et al., to compare between the results of linear and geometrically designed flaps inbicoronal incisions for surgery in the region of the anterior cranial fossa and maxillofacial structures. The authors opinion was that interrupted scalp incisions are better than linear scalp incisions and it should be used in most situations [9]. Munro and Fearon have the same opinion as well regarding bicoronal approach [10] This is the opposite to our results that believe in safety and efficacy of linear scalp incision.

There is another study that recommends the use of linear incisions in forehead approaches done by Anegawa et al., theyused the linear transverse skin incision to approach the frontal area instead of bicoronal incision. Their conclusion was that linear incision has great results regarding cosmoses, safety and efficacy with fewer complications than other incisionswhich conform to our results [11].

In this series we faced minor wound complications in $14 \%$ of cases that is much less than reported in other series. In a study performed by Takanari et al., the operative wound complications rate was $(21.4 \%)$ the minor complications represented $66.7 \%$ of these (superficial necrosis and inflammation), these were treated conservatively, while the major complications rate was $33.3 \%$. (Total flap necrosis and osteomyelitis). The authors found no statistical relation between these complications and the surgical techniques [12].

In a study performed by Abiodun et al., the most common incision used was question mark incision in $14(26.4 \%)$ patients, followed by linear incision in $13(24.5 \%)$ patients. Single layer closure was used in $80.5 \%$ of the patients and multilayered closure was performed in $19.5 \%$ of the patients. Superficial infection was observed in 6 patients with single layer closure; when compared to mul- tilayer closure these complications did not occur. One case developed Cerebrospinal fluid fistula. There was no reported bleeding, necrosis or cosmetic disfigurement [13]

Barry et al., performed a study to evaluate Linear Incision for placement of a Magnetically Coupled Bone-Anchored Hearing Implant and concluded that small linear incision directly placed over the implant is a good choice with the advantages of smaller incision, less hair removal, smaller flap, less operative time, and much reduced pain [14] .

Some authors said that linear scalp incision results in large bad scar [9]. So there is debate in literature between advantages and disadvantages of linear scalp incisions.

\section{Conclusion:}

Linear scalp incision has avery great safety and efficacy in different types of craniotomies. We found the disadvantage of widened scar to be present in few cases and can also occur in other types of scars that may be worse than linear incisions and can be minimized by taking care of langer's lines and vascular territories of the scalp and minimizing use of artery forceps.

\section{References}

1- WILLIAM J., KEMP I.I.I., AARON A. and GADOL C. A review of skin incisions and scalp flaps for the retromastoid approach and description of an alternative technique, Surg. Neurol. Int., 2: 143, 2011.

2- TOLHURST M.D., CARSTENS M.H., GRECO R.J. and HURWITZ D.J.: The surgical anatomy of the scalp. Plast. Reconstr. Surg., 87: 603, 1991.

3- CARMICHAEL S.W.: The Tangled Web of Langer's Lines. Clin. Anat., 27: 162-8, 2014.

4- PAUL S.P.: Biodynamic Excisional Skin Tension (BEST) Lines: Revisiting Langer's Lines, Skin Biomechanics, Current Concepts in Cutaneous Surgery, and the (lack of) Science behind Skin Lines used for Surgical Excisions. Journal of Dermatological Research, 2 (1): 77-87, 2017.

5- JACKSON I.T.: General considerations. In I.T. Jackson (Ed.), Local Flaps in Head and Neck Reconstruction. St. Louis: Thieme, 1: 4-48, 1985.

6- CAMIRAND A. and DOUCET J.A.: Comparison between parallel hairline incisions and perpendicular incisions when performing a facelift. Plast. Reconstr. Surg., 99: 10, 1995.

7- CUTTING C.: Critical closing and perfusion pressures in flap survival. Ann. Plast. Surg., 9: 524, 1982.

8- HOLGERS K.M., TJELLSTROM A., BJURSTEN L.M., et al.: Soft tissue reactions around percutaneous implants: A clinical study on skin-penetrating titanium implants used for bone-anchored auricular prostheses. Int. J. Oral. Maxillofac. Implants., 2, 35-9, 1987. 
9- FRODEL J. and MABRIE D.: Optimal elective scalp incision design. Otolaryngol. Head Neck Surg., 121: 374 7, 1999.

10- MUNRO I.R. and FEARON J.A.: The coronal incision revisited. Plast. Reconstr. Surg., 93: 185-7, 1994.

11-ANEGAWA S., HAYASHI T.,TORIGO R., et al.: Linear Transverse Forehead Incision for Patientswith Alopecia Praematura (Technical Note). Neurol. Med. Chir. (Tokyo), 35: 604-6, 1995.

12- TAKANARI K., ARAKI Y., OKAMOTO S., et al.: Oper- ative wound-related complications after cranial revascularization surgeries. J. Neurosurg., 123: 1145-50, 2015.

13- ABIODUN A., OLUWOLE K., ADEMUYIWA A.O., et al.: Review of surgical scalp wounds closure in ile-ife, NIGERIA. African Journal of Neurological Sciences, 24 (2), 2005.

14- BARRY J.Y., REGHUNATHAN S. and JACOB A.: First Report: Linear Incision for Placement of a Magnetically Coupled Bone-Anchored Hearing Implant. Otology \& Neurotology, 38 (2): 221, 2017.

\section{إستخدام القطع المستقيم \\ فى جراحات الهخ والجمجمة المجائحة المختلفة}

الهقدمة": يعتبر القطع المستقيم لفرة الرآس من آحد آهم القطوع من حيث الآمان الجراحى وتجنب المضاعفات والنتائج التجميلية لفروة

الهدف من الدراسـة: الهدف من هذه الدراسة هو دراسة نتائج هذا القطع وتقييم آثاره وفاعليته فى مختلف جراحات المخ والجمجمة.

تصميم الدراسة: دراسة وصفية إكلينيكية مستقبلية.

طريقة البحث: تم إجراء هذه الدراسة على باع مريض خضعوا إلى إجراء جراحات مختلة المخ والجمجمة نتيجة وجود آورام آو إصابات

آو لآغراض تجميلية آو لآغراض آخرى فى مستشفى بنها الجامعى فى الفترة ما بين يناير عام آلفا وسبعة عثر حتى ديسمبر عام آلفان وتشعة

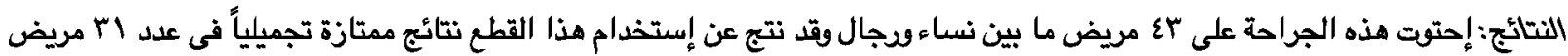
ونتائج جيدة فى عدد ^ مرضى كما حدث إتساع لآثر الجرح في عدد ع مرضى وقد كان هذا الإتساع غير مزعج بالنسبة للناحية الجمالية للمريض.

الخلاصدة: القطع المستقيم فى جراحات المخ والجمجمة قطع ناجع جداً من حيث الفاعلية وتجنب المضاعفات وقد لاحظنا آثناء هذه الدراسة آن نسبة المضاعفات قليلة ومن الممكن حدوثها في القطوع الآخرى ومن الممكن تجنبها بالفهم الجيد ومراعاة تشريع الجمجمة. 